Nippon Suisan Gakkaishi $\quad$ 64(5), 830-840 (1998)

\title{
魚市場の全数調査に基づく宮古湾の ヒラメ種苗放流効果の推定
}

岩本明雄, 大河内裕之, 津崎龍雄, 福永辰広, 北田修一

(1997 年 12 月 1 日受理)

Stocking Effectiveness of Flounder Paralichthys olivaceus in Miyako Bay evaluated by a Fish Market Census

Akio Iwamoto, ${ }^{* 1}$ Hiroyuki Okouchi, ${ }^{* 1}$ Tatsuo Tsuzaki, ${ }^{* 1}$

Tatsuhiro Fukunaga, ${ }^{* 1}$ and Shuichi Kitada ${ }^{* 2}$

\begin{abstract}
This paper assesses the effectiveness of the annual releases (1987-1992) of flounder evaluated by a census of the commercial landings at the Miyako Fish Market, Iwate Prefecture, from 1988 through 1995, where nearly all the flounders fished in the area adjacent to Miyako Bay are landed. Flounders landed were classified into wild or hatchery released individuals by the difference in the pigmentation on the eyeless side of the body. Total length of all the released and almost all the wild individuals which were landed were measured. And we estimated age composition of released fiounder. As a result, from the 611 thousand flounder seeds released from 1987 through 1992, a total of 77,681 were commercially landed, and a contribution rate of the released flounder to the total landings were between $16.5 \%$ and $52.7 \%$. The recapture rate of released seed for each annual release was estimated at between $5.9 \%$ and $23.3 \%$, and the ratio of the total landing cash value to the cost of seeds, including personnel and facilities required prior to release were evaluated at between 0.46 and 1.96. We suggest that improvement of the post-release survival rate may significantly improve the economic returns.
\end{abstract}

キーワード:ヒラメ，放流效果，全数調查，資源係加効率

ヒラメは代表的な栽培漁業の対象種であり，全国で毎 年䄪 2 干万尾の人工種苗が放流されている。豆2)载培漁 業が成立するかどうかを検討するには，経済効果を含め て放流効果を推定することが要求される。標識魚の再捕 報告データから推定した放流効果性偏りが大きく，結果 の信頼性に疑問が持たれることから，近年では市場に水 揚げされた放流魚を直接調查する，いわゆる市場調查法 による放流効果の評洒が主流となっている。ヒラメやマ ダイの上うに広範囲に移動する種類では放流効果の波及 範囲が広く，放流魚注数多くの市場に水揚げされる。放 流魚が水揚げされる範围（調查範囲）の市埸からいくつ かの調查対象市場と調查日を抽出して標本調查が行われ るのが一般的であり，これを2段サンプリングとみて 放流効果を統計的に推定する方法が確立されている。 これまでの分析を通して，放流魚の水掦げ尾数は調査市 場間でばらつく㑯向があり，これに比へると各調査市場
における調查日間のばらつきは少ないことがわかってで た。従って，放流效果の推定精度を上げるには，各調查 市場に打ける調查日数を增やすより，調査市場数を増や す効果が大きいと考えられた。革) ヒラメについては一般 に移動範囲が広く調查古場数む多くなることから，放流 効果が精度良く推定された事例は少ない。一方, 鹿盟島 湾のマダイの放流効果調査5のように，1 つの市場を調 查することによって放流効果の大部分が把握できる場合 は，比較的小規模な調查でも精度の良い推定結果が期等 できる。

岩手県の宮古湾周辺海城は，ヒラメの漁獲量6)が最大 でも 38 トン（近年では10〜20トン）上比較的少量で あり，故流したヒラメの移動出ないことから，少放流 魚の動向が把握しやすく，種苗放流試験の実施に適して いると考えられた。この海域には3〜4 力所の魚市場が 存在するが，主要な市場は宮古魚市場 1 力所であり，

*1 日本钭培漁業協会 (Japan Sea-Farming Association, Uchikanda, Chiyoda, Tokyo 101-0047, Japan).

*2 東京水産大学 (Tokyo University of Fisheries, Konan, Mirato, Tokyo 108-8477, Japan). 
多くの漁業者が漁獲物を宮古魚市場に水揚げする。この ため，この海域からのヒラメの水揚げのおよそ90\%が 宮古魚市場に集中している。的これらの点に着目して, 急本栽培漁業協会（以下，日栽協と略記）宫古事業場で は，宮古湾に括いて1986 年加ら種苗放流試験を実施 しあわせて宮古魚市場に㧍いて水揚げ物調查を行って きた。1988 年以降住放流効果の推定精度を可能な限り 高める目的で，宮古魚市場に括いてヒラメ水揚げ物の全 数誦查を行った。

本論文では，1988年より宫古魚市場で実施した全数 調查の結果に基ついて，1987〜1992 年に放流した 6つ のヒラメ種苗放流群の回収率や経済效果などを推定し， 放流効果を評価する。

\section{材料と方法}

データ 解析の対象とした市場調查データは，全数調 查データが揃っている1988年6月～1996年5月の8 年分である。本論文では，宮古湾におけるとラメの年踰 加算時期を 6 月とし，当年 6 月〜翌年 5 月を同一年龄 の範囲とした。従って，例えば 1988 年の市場調査結果 は，1988 年 6 月〜1989 年 5 月のデータを集計・解析し たものを指す。

本海域で放流したヒラメは，3 歳恋でに回収の大部分 が完了すると考えられる。解析の奴象とする 8 年間の 市場調查データから 1 3 歳魚の回収尾数を全て推定で きるのは，1987〜1992 年の 6 つの放流群である。この 6 群を対象に放流種苗の回収率を推定するとともに，放 流試験を事業とみなして利益率を試算した。

調查海域の概要 調査海域の中心である宮古湾啱手 目の海岸線のほぼ中央に位置し、湾口部の嘾 $5 \mathrm{~km}$ ，奥 行き $10 \mathrm{~km}$ の奥深い内潜である（Fig. 1)。本海域の沿 岸では魚類を詨象として定䈯網，小型定固網，刺秱，廷 縄による漁業が行われて括り，ヒラメはこれら全ての漁 法の漁獲対象となっている。さらに沖合の水深 $200 \mathrm{~m}$ 带付近では沖合底电網漁業が行われているが，ヒラメの 漁㹲訬ない。ヒラメの漁法別漁獲尾数の内訳の推移を Fig. 2 に示した。1988１990年には定置榊（小型定置 網を含む）と延䋥による漁獲が中心でありこれらが全 体の 70\%前後を占めていたが，1991 年以降は刺網に 上る漁獲加增加し，刺絧 1 漁法だけで全体の50\%前後 を漁獲するようになった。本海域沿岸の主幹漁業はサケ 類を対象とした定置網漁業であるが，刺綽や延縄とい。 た小規模释営体にとってはヒラメは重要な漁業資源とな っている。

本海域におけるとラメの漁獾量的は，1956年から 1994 年李での 39 年間の平均が 17.3 トン, 最高漁獾量 は 1963 年の 38 トン, 最低漁獲量は 1982 年の 5 トン

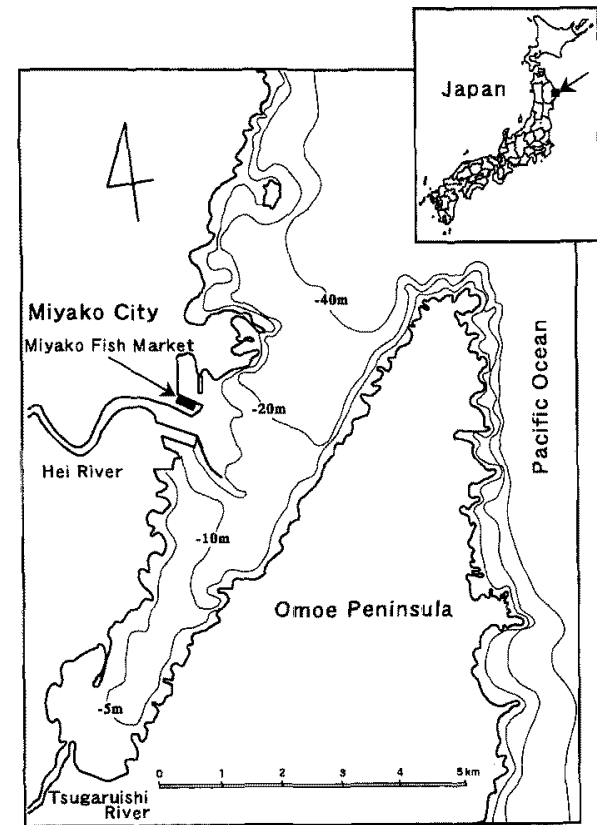

Fig. 1. Geographic features of Miyako bay and location of Miyato Fish Market.

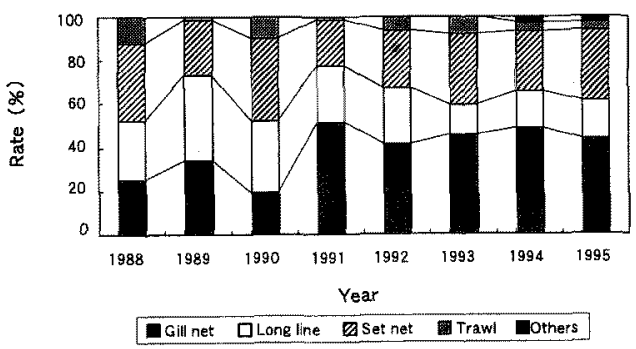

Fig. 2. Changes in composition of the number of landings of flounder by fishing gear.

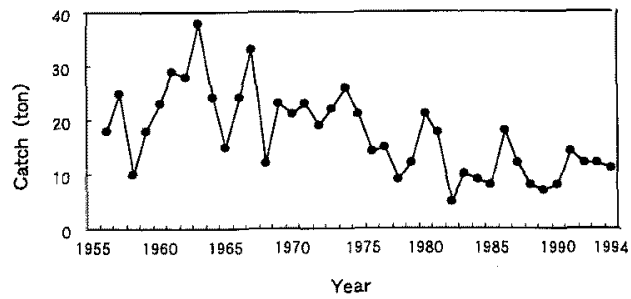

Fig. 3. Changes in catch in weight of flounder landed on Miyako Fish Market. 
Table 1. Statistics on the release of flounder seeds in Miyako Bay

\begin{tabular}{cccccc}
\hline $\begin{array}{c}\text { Year } \\
\text { of } \\
\text { release }\end{array}$ & $\begin{array}{c}\text { Number of } \\
\text { seeds released } \\
(\times 1,000)\end{array}$ & $\begin{array}{c}\text { Mean TL } \\
\pm \text { SD } \\
(\mathrm{mm})\end{array}$ & $\begin{array}{c}\text { Date } \\
\text { of } \\
\text { release }\end{array}$ & $\begin{array}{c}\text { Tagging } \\
\text { method }\end{array}$ & $\begin{array}{c}\text { Tagging } \\
\text { rate } \\
(\%)\end{array}$ \\
\hline 1987 & 157 & $77.7 \pm 17.0$ & Sep. 2,7,10 & Latex & 59.2 \\
1988 & 145 & $81.9 \pm 28.5$ & Aug. 26, Sep. 6, 13 & Latex & 86.9 \\
1989 & 69 & $93.2 \pm 19.0$ & Aug. 23, Sep. 8 & Brand & 100.0 \\
1990 & 80 & $89.5 \pm 13.0$ & Aug. 24, 28 & Brand & 100.0 \\
1991 & 96 & $74.0 \pm 10.2$ & Aug. 7, 28 & Brand & 38.5 \\
1992 & 64 & $77.5 \pm 13.2$ & Aug. 5, 28 & Brand & 31.2 \\
\hline Total(Average) & 611 & $(81.4)$ & & & $(69.5)$ \\
\hline
\end{tabular}

である。漁獲量の推移を Fig. 3 に示した。1960年代の 前期加ら 1970 年代の前期に加けては，年毎に大きく変 動しながらも20〜30トンの水準を保っていたが，これ 以降 1980 年代にかけては減少傾向で推移し，近年では 10 トン程度の低水準で推移している。長期的に見た漁 獾量の推移は減少傾向にある。一方，漁獲量水準は最大 でも $40 \mathrm{t}$ 末渵であり，この海域のとラメ資源は量的に 限定された地域資源であるように思われる。

種苗放流の概要 宮古湾に放流したヒラメ種苗は，全 て日载協宮古事業場で生虐した人工種苗である。これら

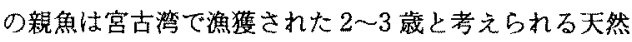
魚を羡成した天然群と，宫古事業場で種苗生産した人工 魚を着成した人工群の 2 群である。種苗生産には各群 から自然産卵によって得られた受精卵を使用した。

1987 1992 年の種苗放流の概要をTable 1 に示し た。放流尾数は年むたり 6.4 15.7万尾，平均放流サイ ズは全長 74.0 93.2 mm の䈥围である。放流種苗には はは100\%の割合で無眼側に黒化部位が認められるた め，漁獲された放流魚の識別にはこれを利用することと し，さらに放流魚の放流年を特定するため，各放流群の 一部らるいは全部に外部から確認できるラテックス標識 (1987，1988 年）あるい暁印標識8)（1989 年以降）を 装着した。テラックス標識とは蛍光色を呈したコム様の ラテックスを注射器によって無眼側の皮下に注入するも のであり，外部から容易に確諗することができる。焼印 骠識とは細く尖った半田ゴテ（商品名はコテライザー；

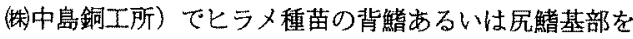
無眼側から貫通させ，火傷跡を標識とするむのである。 焼印標識恃ヒラメの無眼側に円形の透明部位あるいは黒 色色秦の沈着部位として確認できる。ラテックス標識, 印標識ともに背解側と尻鰙側の 2 筒所に毎年交互に 装着し，漁獲時の魚体の大きさと標識の装着部位から放 流年を特定できるようにした。

市場調査の概要 宮古魚市場は岩手県内では久慈, 金
石，大船渡の各市場と並ぶ主要市場の1つであり，宮 古湾周辺海域で漁獲されたヒラメが水揚げされ，これら の大部分が活魚で取引されている。ヒラメを漁獲してい 万定置網，小型定置網，刺網，延縄の 4 漁法の漁場は， 宮古澄内机上ひ湾口加 5 北方 $30 \mathrm{~km} \sim$ 南方 $20 \mathrm{~km}$ に戈 上ぶ $50 \mathrm{~km}$ の沿岸域である。

市場調查の実施にあたっては，専属調查員が年間約 280 日の全ての市場開設日に水揚げされたヒラメを全数 調査した。調查項目は(1)無眼側の黑化部位の有無の確 認, (2)全長の測定, (3)外部標識の有無の確認の 3 項目 である。放流魚の無限側に諮められる人工種苗特有の黑 化部位を利用して放流魚と天然魚を識別した。さらにう テックス標識扰よび橴印標識が確認できる個体（以下， 標識魚という）については，全長の湘定値に標識の種類 と標識部位を付記し，後に放流年を特定した。全長測定 は水掦げされたヒラメの全個体について行うことを基本 としたが，1日の水揚げ量が多く全数測定が困難な場合 には放流魚のみ全数測定とし，天然魚はランダムに抽出 したサンブルについて測定を行った。測定できなかった 天然魚については全て水揚げ尼数を数え，测定サンプル の抽出率を把握した。

この調査の実施に上り，宫古魚市場に水掦げされたヒ ラメの尾数を放流魚上天然魚の別に全て把握し，あわ方 て放流魚の全数と天然魚の大部分についての全長測定テ 一タを得た。さらに，放流魚の一部については装着した 外部標識から放流年度（年絵）を特定できた。

水揚げ重量，水揚げ金額，および種苗放流経費の算出 市場調査加ら得た全展測定データをむとに，北川ら9゙が 太平洋北部沿岸のヒラメ天然魚の涺定に基ついて推定し た全長と体重の関係式を用いて全長别の個体重を求め, これを程算した月別あるいは年龄別の水揚げ重量を算出 した。

水揚げ金額の算出には铭柄別単価が必要であるが，宮 古魚市場では每日の平均単価の及記録さ扎ており銘唡别 
単洒が得られないため，宫古魚市場と同様にとラメを活 魚で报っている岩手県三陸町の綾里角市埸の 1992 年の 月別銘柄別単価データを用いた。各銘柄に含まれる個体 重の䈒囲がわかっているので，この情報から体重别単価 を求め（例えば鉆柄 $\mathrm{A}$ の体重範囲が $400 \sim 800 \mathrm{~g}$ の場 合、この体重籍围に含末れる個体には銘柄Aの単価を あて估める)，これと各佰体の体重の皘加ら個体別の金 類を算出した。これを積算して月別あるいは年踰別水揚 げ金額を算出した。この方法によって算出した 1992 年 6 月 1993 年 5 月の 1 年間の平均単洒汢 2,235 円 $/ \mathrm{kg}$ であり，同じ期間の宫古魚市場の実際の平均単洒 2,182 円/kg との間には大きな差嶍められなかった。なお， 宮古焦市場では放流魚についてむ天然魚と同じ単価で取 り极われている。

日裁拹宮古事業埸に括けるヒラメ種苗 1 尾むたりの 種苗放流単価は，種苗生産経費，施設償却費，人件費を 含めて $15 \mathrm{~mm}$ 種苗では 3.9 月， $30 \mathrm{~mm}$ では 8.2 円， $50 \mathrm{~mm}$ では 33.5 円，100 $\mathrm{mm}$ では74.5 円上試算され ている。 1尾あたり単洒を 35 円， $60 \mathrm{~mm}$ では 45 円，70 mmで は 50 円， $80 \mathrm{~mm}$ では 60 円，90 mmでは 70 円，100 mm では 80 円と設定し，種苗放流経費を算出した。

なお，水掦げが集中したために天然魚の全長測定㑑体 をサンプル抽出した場合には，測定サンブルの全長組成 から求めた水揚げ重量㧍よび水揚げ金額を抽出率で除し て，I力月每に天然焦の総水揚げ重量むよび緿水揚げ金 積を推定した。天然魚の水揚げ尾数全体からの測定サン プルの抽出率は 1988 年は $40 \%$ と低いが，1989年は $75 \%, 1990$ 年以降は $90 \%$ 以上である。

放流魚の貢献率の測定 ヒラメの水揚げ全体に占める 放流魚の割合を貢献率と呼ぶ。ここでは宫古魚市場に拉 ける水揚げを調查海域全体からのものとみなし，水掦げ 尾数，水掦げ重量，水揚げ金額の3つの項目について 各々貢献率を求めた。水掦げ尾数での貢献率は全数調査 に基つく実測值であり，水揚げ重量むよび水掦げ金額で の貢献率は，前述した算出方法に基つく推定値である。 なお，水揚け尾数に占める放流魚の割合は一般に混獲率 あるいは淈入率と呼ばれるが，本論文では一括して賁献 率とした。

放流魚の年齡組成の推定 テラックス㧍上び㜔印標識 魚の再捕データをもとに年龄情報（年龄の特定された個 体群の平均全長とその標準偏差）を整理しここれ用い て放流魚の全長組成を年路別に分解する方法11によ。 て水掦げされたとラメ放流魚の年龄組成を推定した。解 析の対象之した 8 年間に宮古魚市場に水揚げされた放 流魚は合計 90,156 尾であり，このうち標識魚は 24,020 尾（放流魚全体の $26.6 \%$ ）であった。標識魚の

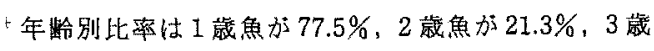
魚以上が 1.2\%であった。3 䵧以上では標識魚の再捕が 少なくなり，有効な年跲情報が得られにくいと判断した こと，また，本海域での漁㛎の中心は 1 2 藏魚と考え られることから，月別平均全長と平均全長の標淮偏差が 得られる1歳魚抢よび 2 歳魚をはじめに分離し，牫り を一括して3歳以上と推定した。たたし，1988 年につ いては 2 歳魚の標識再捕データが少なかったことと，3 歳魚に放たる 1985 年群が放流されておらず，3歳魚以 上の水揚げが非常に少ないと考えられたことから，年踰 情報を用いた分離は 1 藏魚のみとし，残りを 2 歳魚以 上とした。推定はすべて1カ月毎にデータをプールし て行った。

回收來之利益率の推定 放流魚の年龄組成の推定結果 加ら各放流群の回取尾数拈よひ回取率を求めた。さらに 回収金額と放流経費を前述した算出方法により推定し, 放流経費を回收金額で除して利益率を求めた。なお，3 歳打よびそれ以上の年龄群については調查年毎に一括し て㷊計した。

ラテックスおよび焼印標識の残存率の推定 年跲組成 の推定結果加ら得られた各放流群の水揚げ時点ての放流 魚全体に占める標識魚の比率之，各放流群の放流時点で の標識装着率（Table 1）から，ラテックス標識および 焼印標識の残存率を推定した。推定は，本海域でのヒラ メの水揚げの盛期である 6 11月の6カ月間のデータ をプールして年龄每に行った。推定期間の起算日（放流 日）を 8 月末日として，1藏での標識残存率の推定期間 を放流後 $10 \sim 15$ 力月, 同様に 2 藏では放流後 $22 \sim 27$ 力月， 3 歳以上で放流後 34 力月以上とした。

\section{結果}

放流魚および天然魚の漁獲動向 調查を行った 8 年 間に宫古魚市場に水揚げされたとラメ放流魚は合計 90,156 尾，各調查年每の水揚げ尾数は 4,394 19,415 尾の範囲に汸った。天然魚は合計 177,982 尾が水揚げ され，各調查年における水揚げ尾数は 8,020 38,109 尾 の範囲にあった。むた，各满査年における放流魚の水掦 げ重量は 810〜6,366 kg，水揚げ金積は887〜10,218千 円と撨定された（Table 2)。放流魚の水掦げ尼数け 1988 1992 年の間には年々增加する傾问がみられる が，1993 年以降は减少傾向に轱している。天然魚の水 揚げ尾数には1989年と1990年にそれそれれ急激な減少 および增加が認められるか，これ以外は各年とも2.0 2.4 万屁の籍围で安定している。

放流魚の漁獲への貢献率 1988 1995 年の 8 年間に 朽ける平均貢献染は，水揚げ尾数では $33.6 \%$ ，水揚げ 重量では $27.7 \%$ ，水揚げ金額では $22.7 \%$ となった（Ta- 
ble 2)。各項目における貢献率が最も高い年は，水揚げ 尾数では 1989 年の $52.7 \%$ ，水揚げ重量では 1992 年の $38.1 \%$ ，水掦げ金額では 1991 年の $29.9 \%$ であり，そ れぞれの年㦏なっている。

各項目に打ける貢献渠は 1989 年に急激に上昇し，以 降は高いレベルで推移しているが，1995 年に再び低下 している。1988〜1995 年の宮古湾におけるサイズ別平 均貢献率（尾数）は，全長 $30 \mathrm{~cm}$ 未满では23.4 66.9\%(8 年間の平均は 49.4\%), 30 40 cm では 4.4 $41.6 \%$ (同 $30.1 \%$ )，40 cm 以上では $0.9 \sim 32.4 \%$ (同 18.5\%) であり，小型魚ほと混入割合が高い傾向があ る。1995 年 7 月より岩手県下で全長 $30 \mathrm{~cm}$ 末満のヒラ メの漁獲を禁止する自主規制が眹入され，放流魚の混入
割合夯高い小型魚の水揚げが減少したため，1995年の 貢献率は全般的に低下している。

放流魚の年齡組成と年龄別の漁獾動向 各調查年に古 ける放流魚の年榆組成の推定結果のうち，この海域にお けるヒラメの水揚げの盛期である 6 月〜 11月の6 力月 分をFig. 4 に示した。1989，1990 年には各年跲群の全 長組成の分布籍囲，特に2 歳魚の分布範围が広いため に，1,2 盛魚の全長組成の重なりが大きくなっている。 これとは刘照的に 1991〜1994 年については，1，2 歳魚 の全長組成の重なりが少なく，それぞれの分布範困が明 瞭に分汃れている。1995年については，この年の7月 から前逊した全長 $30 \mathrm{~cm}$ 未満の漁獲自主規制が導入さ れたため，1藏魚の一部は 6 月に漁獲加入したものの，

Table 2. Result of the census of flounder in the Miyako Fish Market. Released flounders were identified by pigmentation on the eyeless side

\begin{tabular}{|c|c|c|c|c|c|}
\hline $\begin{array}{c}\text { Survey } \\
\text { year }\end{array}$ & Landings & $\begin{array}{l}\text { Released } \\
\text { fish }\end{array}$ & $\begin{array}{l}\text { Wild } \\
\text { fish }\end{array}$ & $\begin{array}{l}\text { Total } \\
\text { fish }\end{array}$ & $\begin{array}{l}\text { Contribution } \\
\text { rate }(\%)\end{array}$ \\
\hline \multirow{3}{*}{1988} & Number & 4,394 & 21,659 & 26,053 & 16.9 \\
\hline & Weight & 810 & 9,087 & 9,897 & 8.2 \\
\hline & Income & 887 & 22,613 & 23,500 & 3.8 \\
\hline \multirow{3}{*}{1989} & Number & 8,926 & 8,020 & 16,946 & 52.7 \\
\hline & Weight & 2,059 & 3,568 & 5,627 & 36.6 \\
\hline & Income & 2,621 & 8,782 & 11,403 & 23.0 \\
\hline \multirow{3}{*}{1990} & Number & 15,311 & 38,109 & 53,420 & 28.7 \\
\hline & Weight & 4,642 & 11,122 & 15,759 & 29.5 \\
\hline & Income & 7,591 & 18,257 & 25,849 & 29.4 \\
\hline \multirow{3}{*}{1991} & Number & 14,923 & 21,854 & 36,777 & 40.6 \\
\hline & Weight & 5,078 & 9,646 & 14,727 & 34.5 \\
\hline & Income & 9,185 & 21,585 & 30,770 & 29.9 \\
\hline \multirow{3}{*}{1992} & Number & 19,415 & 20,626 & 40,041 & 48.5 \\
\hline & Weight & 6,366 & 10,359 & 16,725 & 38.1 \\
\hline & Income & 10,218 & 27,163 & 37,381 & 27.3 \\
\hline \multirow{3}{*}{1993} & Number & 12,437 & 23,396 & 35,833 & 34.7 \\
\hline & Weight & 4,705 & 10,265 & 14,970 & 31.4 \\
\hline & Income & 8,672 & 21,966 & 30,638 & 28.3 \\
\hline \multirow{3}{*}{1994} & Number & 10,051 & 20,474 & 30,525 & 32.9 \\
\hline & Weight & 3,682 & 10,270 & 13,952 & 26.4 \\
\hline & Income & 6,936 & 24,630 & 31,566 & 22.0 \\
\hline \multirow{3}{*}{1995} & Number & 4,699 & 23,844 & 28,543 & 16.5 \\
\hline & Weight & 2,498 & 13,423 & 15,921 & 15.7 \\
\hline & Income & 6,179 & 33,210 & 39,389 & 15.7 \\
\hline \multirow{3}{*}{ Total } & Number & 90,156 & 177,982 & 268,138 & 33.6 \\
\hline & Weight & 29,840 & 77,740 & 107,578 & 27.7 \\
\hline & Income & 52,290 & 178,205 & 230,496 & 22.7 \\
\hline
\end{tabular}

Weight; $\mathrm{kg}$, Income; 1,000 yen. 


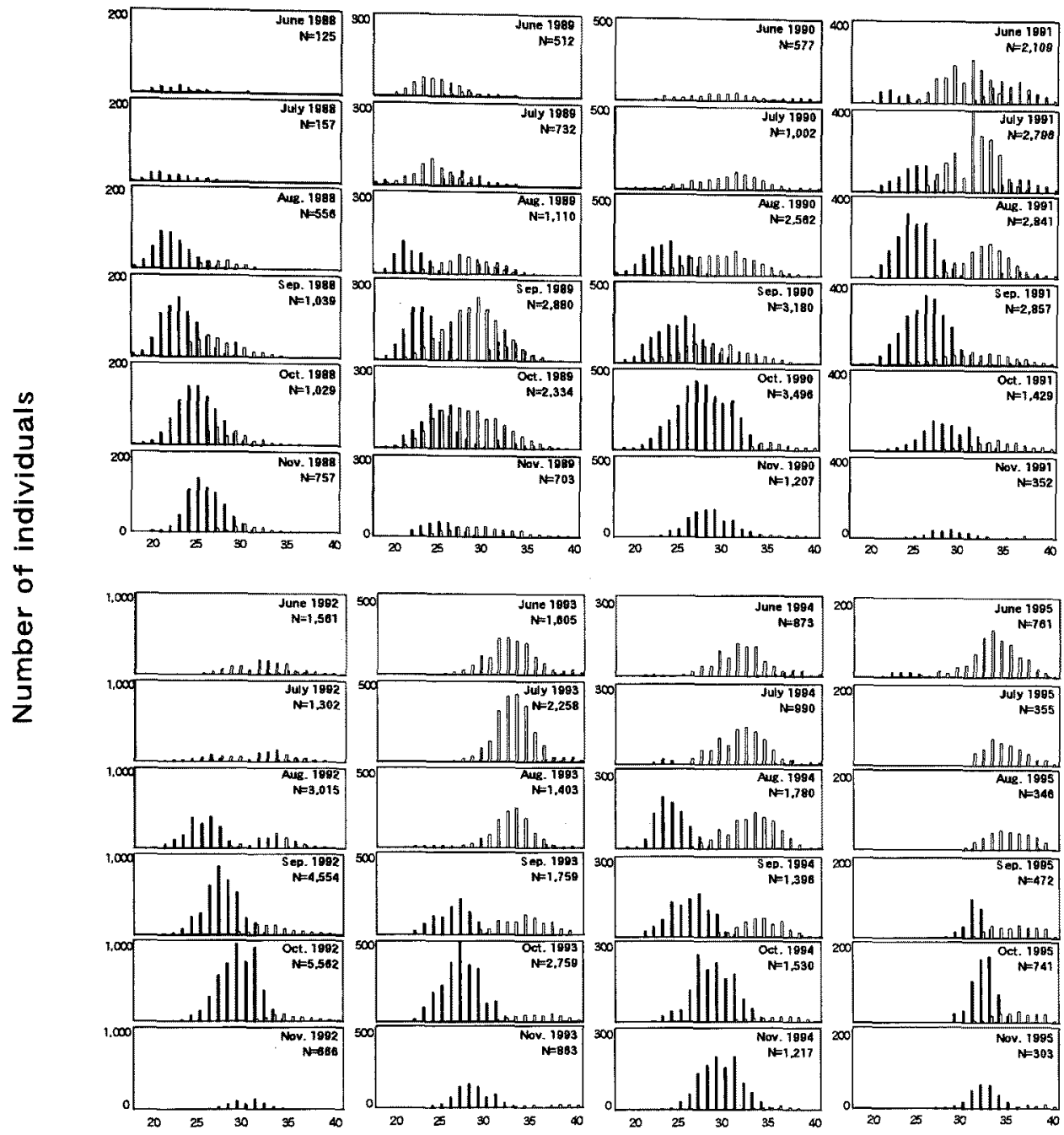

Total length $(\mathrm{cm})$

$\square 1+\square 2+\square \geqq 3+$

Fig. 4. Estimated age compositions of flounder released in Miyako Bay from 1988 through 1995.

7〜8月には全く潐獲されていない。9月以降には 1 歳 魚が全長 $30 \mathrm{~cm}$ 越えて再び漁獲され始めている。

1 藏魚の漁獲加入時期は年により異なっており， 1991 年には6７月，1988，1989，1990，1992，抢よひ 1994 年には 8 月，1993 年には 9 月以降に本格的に港獲 加入している（Fig. 4)。宮古潜ではこの時期に漁具の 設置場所や漁獲王が大きく变化することはないので，1
藏魚の漁獲加入は，宮古潜の湂奥部等の漁業が存在しな い海域で生息していたヒラメ1歳魚が，成長とともに 漁埸へ移動することによって起こると考えられる。

放流魚の回収率と利益率 各放流群の年㱓別回収尾数 および回收率の推定結果夲 Table 3に示した。1987， 1988 年放流群の回收率は $5.9 \sim 6.9 \%$, 平均回收率は 6.4\%であったが，1989〜1992 年の4つの放流群では 
Table 3. Estimated number of returns and return rates of flounder released in Miyako Bay from 1987 through 1992

\begin{tabular}{|c|c|c|c|c|c|c|}
\hline \multirow{2}{*}{$\begin{array}{l}\text { Year of } \\
\text { released }\end{array}$} & \multirow{2}{*}{$\begin{array}{l}\text { Number of } \\
\text { seeds released }\end{array}$} & \multicolumn{3}{|c|}{ Number of returns } & \multirow{2}{*}{ Total returns } & \multirow{2}{*}{$\underset{(\%)}{\text { Return rate }}$} \\
\hline & & $1+$ & $2+$ & $\geqq 3+$ & & \\
\hline 1987 & 157,000 & 3,448 & 5,143 & 702 & 9,293 & 5.9 \\
\hline 1988 & 145,000 & 2,751 & 5,605 & 1,715 & 10,071 & 6.9 \\
\hline 1989 & 69,000 & 9,004 & 5,994 & 1,112 & 16,110 & 23.3 \\
\hline 1990 & 80,000 & 7,214 & 4,808 & 728 & 12,750 & 15.7 \\
\hline 1991 & 96,000 & 13,495 & 6,645 & 643 & 20,783 & 21.6 \\
\hline 1992 & 64,000 & 5,064 & 3,426 & 244 & 8,734 & 13.6 \\
\hline Total & 611,000 & 40,976 & 31,621 & 5,144 & 77,741 & $(12.7)$ \\
\hline
\end{tabular}

Table 4. Release cost, estimates of landing cash value from released flounder, and economic return rate in Miyako Bay

\begin{tabular}{ccccccc}
\hline Year & $\begin{array}{c}\text { Release cost* } \\
(\mathrm{A})\end{array}$ & \multicolumn{2}{c}{\begin{tabular}{c} 
Landing cash value from released fish* \\
\cline { 3 - 6 }
\end{tabular}} & $\begin{array}{c}\text { Total landing } \\
\text { cash value*(B) }\end{array}$ & $\begin{array}{c}\text { Ecomomic teturn } \\
\text { rate }(\mathrm{B} / \mathrm{A})\end{array}$ \\
\hline 1987 & 9,420 & 475 & 1,553 & 2,313 & 4,341 & 0.46 \\
1988 & 8,700 & 331 & 3,939 & 3,478 & 7,202 & 0.83 \\
1989 & 4,830 & 1,890 & 4,273 & 2,841 & 9,004 & 1.86 \\
1990 & 5,600 & 1,434 & 4,052 & 2,236 & 7,722 & 1.38 \\
1991 & 5,760 & 3,328 & 5,366 & 2,613 & 11,307 & 1.96 \\
1992 & 3,840 & 1,070 & 2,656 & 1,432 & 5,158 & 1.34 \\
\hline Total & 38,150 & 8,528 & 21,293 & 14,913 & 44,734 & $(1.17)$ \\
\hline *1,000 yen. & & & & & &
\end{tabular}

回収率が向上し，13.6〜23.3\%となった。後者の平均 回収率は $18.9 \%$ であり，前者の抢よそ3 倍であった。 回收率が高かった 1989 1992 年放流群では，各群の節

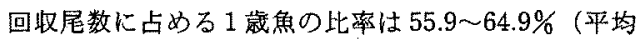
$59.6 \%$ )，2 藏では $32.0 \sim 39.2 \%$ (平均 35.6\%)，3 藏以 上では 2.8～6.9\%（平均 $4.8 \%$ ）となっており，1歳魚 での回取が最も多くなっている。これに対し，回収率が 呧かった 1987，1988 年放流群では 1 藏より2藏での回 収が多くなっている。後に述へるように，1987，1988 年放流群は他群に比べて放流啳の成長が劣っていたため に，1歳魚で漁獲加入した個体が少なかったものと考え られる。

各放流群の年龄別回收金額および利益率の推定結果を Table 4 に示した。各放流群の回収金教は 4,341 11,307千円々推定された。回収率が低かった 1987， 1988 年放流群では利益率が 1 を下回ってマイナスとな ったが，回収率が向上した 1989 年以降の放流群では水 揚げ金額が種苗放流経費を上回って打り，利益率は 1.34 1.96 の範团であった。回取率が高かった 1989〜 1992 年放流群で古，各群の総回収金類に占める 1 歳魚 での回収金額の比率は 18.6２9.4\%（平均 23.3\%), 同
様に 2 歳魚では $47.5 \sim 51.5 \%$ (平均 $49.3 \%$ )，3 歳魚以 上では 23.1 31.6\%（平均 27.5\%）となって打り，金 額の面では 2 歳魚の回収が主力になっていることがわ かった。

推定した 6 群の回取率抢上び利益刺のデータ系列に は $r=0.975$ の正の相関が琶められ（Fig. 5)，利益率は 回收率に主に依存していることがわかる。ここから得ら れた一次回帰式 $y=0.0782 x+0.1713$ 上り，宫古海では 回收率が 10.6\% を越えると利益率が1を上回ると考え られた。

ラテックスおよび焼印標識の残存茶 各放流群の標識 残存蜼の推移をFig. 6に示した。ラテックス標識を装着 した 1987, 1988 年放流群の標識残存率は，1筬では 71.3 73.3\% と高いが，2葴では 4.5〜23.3\%に低下 し，3歳以上では 0 7.1\%であった。焼印標識を装着 した 1989 1994 年の各放流群のうち，1991～1994年 の 4 群については，1歳では 80.0〜98.4\%，2 歳では $39.7 \sim 51.4 \%$ (1991 1993 年の3 群)，3歳以上でむ 21.5 35.8\% (1991〜1992 年の 2 群) とラテックス骠 識に比へて高い残存率であった。一方，1989，1990年 2 群については，同じ筧印標識でょるのに残存率が低く， 
1歳では 44.4〜 47.1\%，2 歳では 15.5〜29.0\%，3 藏以 上ては3.0〜20.9\%であった。1989, 1990 年放流群の炇 田標識には市肘の半田コテをそのます用いたが，チップ 的先端が太く勇体を貫通させうらかったため，1991年 以降壮チップを改良し，先端を細く成形するととむにテ フロン加工を施した。1991 年以降の放流群で焼印標識 の牫存率が向上したのは，チップの改良によってより確 実な標識付けが可能になったためと考えられる。

放流魚の成長 ラテッックス拉よび㜔印標識魚の再捕デ 一タ加ら求めた放流焦の月別平均全長を放流群每に図示

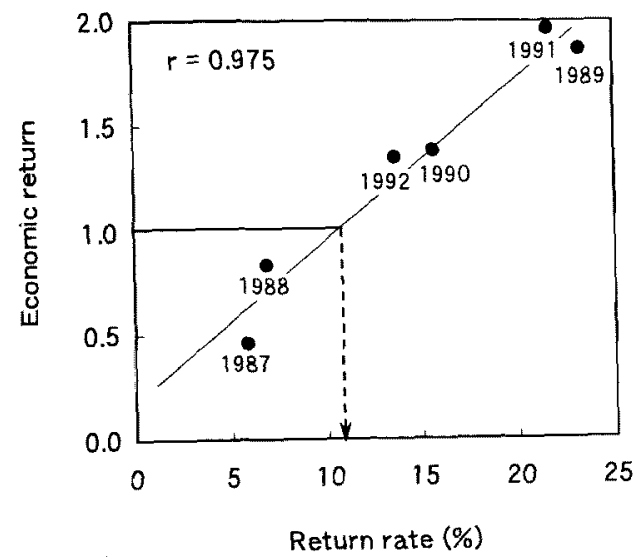

Fig. 5. Relation between return rate and economic return.

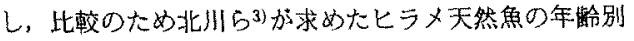
全長 (堆婎の平均值)を併記した（Fig.7)。放流魚の

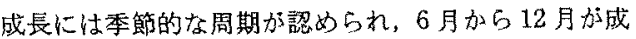
長期，1月只 55 月が成長の停滞期と見ることができ る。回收率の低加った 1987，1988 年放流群は，他に比 ペて明らかに成長が少っている。1989 1992 年放流群 では群により成長が若干巽なるむのの，天然魚と抙色の ない成長が惩められた。

考察

放流群により回收率に差が生じた原因 回牧率が高か った 1989〜1992 年の4つの放流群と，低かった 1987， 1988 年の 2 つの放流群では，平均回取率におよそ3倍 の美が生じた。日栽協宫古事業場のヒラメ種苗生産に括 いては，成長の遲れた種苗を選别し，順調に成長してい る種苗とは別の水槽で飼育を行っている。回收率が高か った 1989 1992 年放流群には順調に成長した種苗のみ が使用されているのに対し，回取率が低かった 1987， 1988 年放流群には主として成長が连れた種苗が使用さ れていることから，使用された種苗の䔔いによって回收 率に差が生したと考えられる。成長が拈れた種苗を用い ると回収率が低下する理由の1つとして，成骎の羊れ に伴う放流サイズの小型化や放流時期の遅れ等が考えら

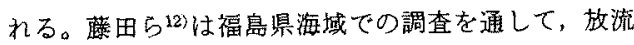
時期が漣れて水温下降期にず机込むと，放流魚の成長が 悪く再捕率も低くなることを指摘している。はた和本” は1991年以降に宮古湾に摽識放流したとラメ䡚苗の一

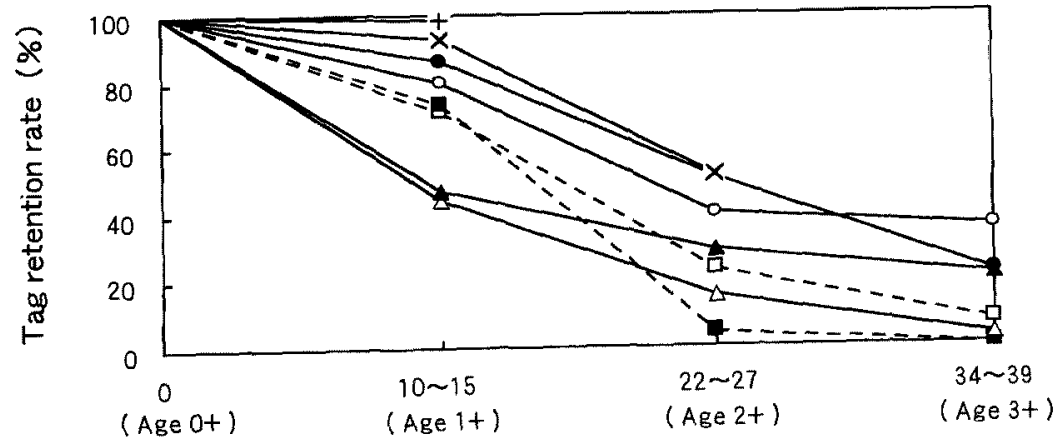

Months after release

\begin{tabular}{|c|c|c|c|c|c|c|}
\hline$\square$ & 1987 & $\Delta$ & 1989 & 0 & 1991 & $\times 1993$ \\
\hline 1 & 1988 & A & 1990 & - & 1992 & +1994 \\
\hline
\end{tabular}

Fig. 6. Estimated tag retention rates for every release group.

Solid lines show brand tag and broken lines show latex tag.

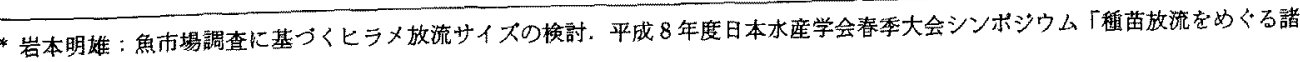
問題」. 


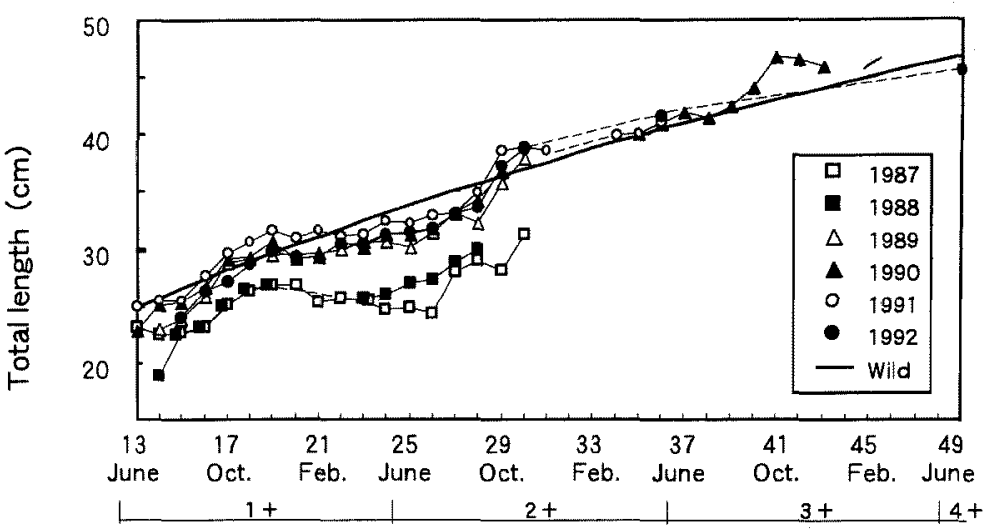

Months after release, and year class

Fig. 7. Growth of released flounder for every release group.

Mean total length of released flounder obtained from tagged fish was plotted with an expected growth curve which is calculated as a mean from growth equation $L t=896.6 \cdot\left(1-e^{-0.1576 \cdot(t+1.238)}\right)$ ( $)$, $L t=592.1 \cdot\left(1-e^{-0.2735 \cdot(t+1.151)}\right)$ ( $\delta$ ) obtained by Kitagawa et al. (1994).

定期間の回收率を比較した結果から，添加効率13)の面 では大型サイズの放流が有利であることを示照してい る。宮古湾において回收率が低加った1987，1988 年放 流群の放流サイズは，ほほ同し時期に放流している 1989 年放流群に比ぺて全長が $11.3 \sim 15.5 \mathrm{~mm}$ 小型であ り，放流日（2３回に分けて放流しているのでその最 終日）についてむ1990年以降の放流群と比へて13〜 16 日连くなっている。しかし，この違いから回収率に 3 倍の差が生しるかか否かについては, さらに詳細な検討 を要する部分であるう。この他，種苗そのむのの活力に 問題があり，放流後の減耗が大きったことむ考えられ る。また，回取率の高かった 1989〜1992 年放流群には 全て焙印標識，低かった 1987,1988 年放流群にはラテ ックス標識を使用しており(Talbe 1)，標識装着の影響 により回収率に差が生した可能性も否定できない。

本海域では放流魚の漁場外への移動は少なく7)各放流 群の逸散状況に差はないと考无られる。従って，各放流 群間で逸散量に差があるために回収率に差が生した可能 性は少ないと考えられる。次に，本海域に抢ける定圈網 の設置数や，刺網，延縄に從事する漁業者数は各年で大 きく変化していないので, 各放流群に対する漁獲王む大 きく変和らないと考えられる。かつ, 各放流群の自然死 亡についても，漁獲加入した全長 $20 \mathrm{~cm}$ 以上の個体で 大きな差があるとは考えにくい。とすると，漁攃加入以 降に放流群間の死亡率に差が生じる可能性は大きくはな い。これらのことから，著者らは各放流群の回収率の差

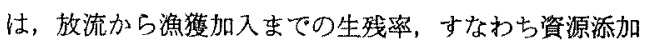

效率13)の差に起因している可能性が大きいと考えてい る。

放流効果の評価と今後の課題 本調查では，ヒラメ放 流魚の動向が把暒しやすい宮古饬を調查海域として，宫 古魚市場に村ける全数調查の実施と，標識魚の放流に上 る年龄情報の確保，およびその情報を利用した年跲組成 の推定法の導入という計画的な調査・解析を実施し，推 定値の信頼性を高めるよう努めた。そして，宮古湾にお ける 1987 1992 年の6 つのヒラメ種苗放流群の回収率 を5.9〜23.3\%，平均回取率を $12.7 \%$ と推定した。 1989 年以降の放流群では 1.34 1.96 倍の簀囲で回収金 額が放流経費を上回っているむのの，今後ヒラメ種苗放 流を経済的に成立させるには，利益率をできるたけ高い 水準に安定させる必要があると考えられる。

本解析を通して，とラメ種苗放流の利益率は主に回収 率に低存しており，回収率は資源添加効率の影響を受け ていると考えられた。とラメの種苗放流效果を向上させ るには，資源添加効率の向上が重要な課題となるう。具 体的な取り組み方法としては放流時期，放流場合，放流 サイズ，交るいは種苗の筫等を検討項目とした同時放流 試験が考えられるが，いずれの場合においても，資源添 加效率を直接あるいは間柆的に比渂する手法（例えばサ ンプリング調查から推定した初期死亡率の比較や，市場 調査から把握した 1 蒜魚の漁獲加入尾数の比較等）を 開発することにより，效率的な放流技街開発が可能にな ると考えられる。

むう一つの課題としては，種苗生産・放流释費の低減 
による利益率の向上があげられる。前述した日载協宮古 事業場におけるヒラメの種苗放流経費は，ほぼ限界と思 われるはど節减されているが，画期的な種苗生産方法の 開発等により更なる低コスト化を検討してゆく必要が就 ろうे。

一方，漁獲方法の改善によってむ利益率を向上させる ことが可能と考えられる。岩手県下では既に1995 年 7 月から全長 $30 \mathrm{~cm}$ 未満のヒラメの漁獲自主規制方導入 されておりこの規制の效果が注目される。規制が導入 された 1995 年の放流魚の年龄組成（Fig. 4）をみると， 1藏魚に相当する小型のヒラメの水揚げが減少している ことがわかる。この規制が有効に譏能すれば， 1 歳魚の 大半が保護されて経済的に洒值の高い 2 歳魚以上の漁 濩加增加すると考えられ，ヒラメ漁業全体の経済効率の 向上とともに，ヒラメ種苗放流の利益率の向上む期符さ 斿る。

全数調査によって得られた放流魚の日別水揚げ尾数デ 一タのうち 1992 1995 年の 4 年分を用いて，調查日数 を変化させた場合に，放流魚の総水揚げ尾数の推定值が どの程度変動するかを检討した。市場の開設日が年間 $N$ 日あり，そのうち $n$ 日について水揚げされた放流魚 を全て調查した場合，放流魚の緿水揚げ尾数は

$$
\hat{T}=\bar{y} \cdot N
$$

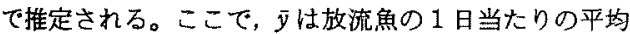

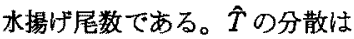

$$
V(\hat{T})=N^{2} \cdot \frac{N-n}{N-1} \cdot \frac{\sigma^{2}}{n}
$$

で評価さ扎るが，日間分散 $\sigma^{2}$ は

$$
\sigma^{2}=\frac{1}{N} \cdot \sum_{i=1}^{N}\left(x_{i}-\bar{x}\right)^{2}
$$

として全数調查データから得ることがでる。Fig. 8 K，調查日数 $n$ に対する放流魚の総水揚げ灵数の推定 精度を変動係数 (CV) で示した。1993 1995 年につ

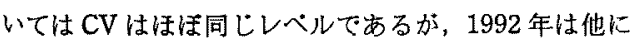
比べ若干高かった。推定值の許容誥差をどの程度に設 定するかは予算や労力に左右されるが，もし，CV を 10\%以下にしたい場合は，1993１995年の場合で 80 90 日，5\%以下にしたい場合は 170 180 日程度の 調查が必要と考えられた。な抢，この調査日数の検討 は，1年間の市場開設日を単純ランダムサンブリングに よって抽出する前提であるが，水掦げ量等を基準に時期 や眼日で層別にサンプリングすると，同じ調查学力でむ 更に推定精度が向上すると期待される。層別した場合の 推定精度の検討については今後の課題としたい。

\section{謝辞}

本論文のとりまとめにあたり，有益なご助言とご校閲

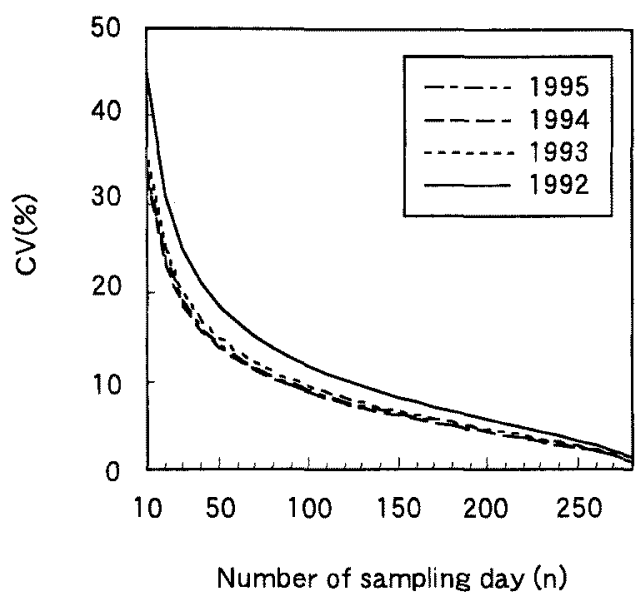

Fig. 8. Relation between number of sampling days of fish market survey and $\mathrm{CV}$ of estimated recaptures.

を頂いた社日本栽培漁業協会技術アドバイザ一須田 明 博士に深謝申し上げる。本調查を行うにあたり，ご助語 を頂いた水㕍庁東北区水産研究所魚介類增殖研究室の山 下 洋室長をはじめとする皆様方に感謝申し上げる。市 場調查にご協力頂いた宮古围市場の瞕貝の㫮様方，およ び各種調查にこ協力頂いた宮古漁業協同組合高浜種苗セ ンターの佐々木常雄係長をはじめとする職員の方々に厚 くお礼申し上げる。最後に，宮古魚市場において専属調 查員として調查に携わった佐々木昭治氏に㳭く感謝申し 上げる。

\section{文献}

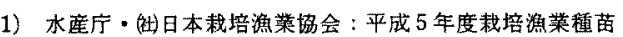

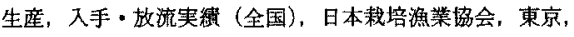
1995, p. 109.

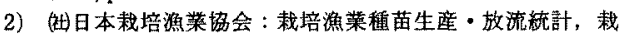
培資源謂查検討資料，11，日本㦵培漁業協会，東京， 1995 , p. 141.

3）北田㘳一，岸野洋入，多㽞保志：2 段抽出の市場調查に上 る種苗放流効果の推定. 日水誌，59，67-73 (1993).

4) S. Kitada, Y. Taga, and H. Kishino: Effectiveness of a Stock Enhancement Program Evaluated by a Two-Stage Sampling Survey of Cornmercial Landings. Can. J. Fish Aquat. Sci., 49, 1573-1582 (1992).

5）椎原久幸；鹿児島湾における放流の成果と䦓題点，「マダ 1の資源培暴技術」(田中 克, 烃宮義啨編)，但星社垾生 閧, 東京, 1986, pp. 106-126.

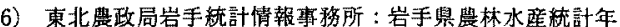
報 (水産編)，岩手県農林縄訢㙝会，岩手，昭和 31 年 平成 7 年.

7) 日本裁培漁業拹会：日本载培源業協会事業年報（平成元年

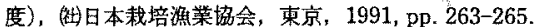

8）酒畸能雄，能谷厚志：ヒラメ焼印標識の可能性について. 平成 2 年度東北ブロック增蓝殖研究連絡会議報告書, 東北 フロック增䍸殖研究会, 5-12 (1991) 
9）北川大二，石户芳里，桜井寒憲。福永辰広：三筀北部治 岸に抢けるヒラメの年羭，成長，成热. 東北水研報， $\mathbf{5 6}$, 69-76 (1994).

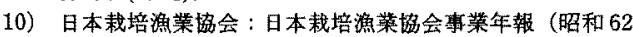
年度)，活日本载培漁業㙝会，東京，1989，pp. 146.

11）大河内裕之，北田悠一，岩本明雄：漂識再捕の年踰饽報 を用いた放流魚の体长組成の年䏩分解法。日水誌（印梮
中).

12）藤田恒婎，水野拓治，根本芳春：福島県におりるヒラメ 人工栕苗の放流始果について。偊培技研，22,67-73 (1993).

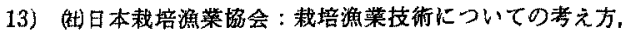
1，日本栈培漁業協会，東京，1989，p. 18. 